[Agr. Biol. Chem., Vol. 30, No. 12, 1175 1182, 1966]

\title{
Isolation and Determination of Yeasts Utilizing Kerosene as a Sole Source of Carbon
}

\author{
By Ikunosuke TANABE, Jitsuo OKada and Hideo ONo \\ Fermentation Research Institute, Agency of Industrial Science and Technology, \\ Ministry of International Trade and Industry
}

Received April 27, 1966

\begin{abstract}
In order to produce microbial cell substances from petroleum, 83 strains of keroseneutilizing yeasts, as a sole source of carbon, were isolated from 37 materials in contact with petroleum in the petroleum refinery. They could be distributed in either of 15 cultural groups with their colony appearances. Fifteen representative strains in 15 cultural groups were served for determination and identified with the following species: Candida tropicalis, 9 strains; C. guilliermondit, 2 strains; C. intermedia, 2 strains; C. pulcherrima, 1 strains; Torulopsis pinus, 1 strain.

In order to clarify what the ability of hydrocarbon utilization means biologically, 46 standard strains were served for test, of which the following 5 strains could utilize kerosene as a sole source of carbon: Candida albicans IAM 4888; C. arborea IAM 4147; C. lipolytica IAM 4947; C. tropicalis IAM 4862 and IAM 4924. Considering the result, the ability of utilizing kerosene would seem to characterize the genus, but it was not evident that it would characterize the species.

C. tropicalis $\mathrm{Pk}-233$ gave the best cell yield among the above strains when kerosene was employed as a sole source of carbon and moreover, in the production of the cells of $\mathrm{Pk}-233$, employing kerosene as a carbon material was compared with employing glucose.
\end{abstract}

\section{INTRODUCTION}

It has been known that some microorganisms could utilize hydrocarbon as a sole source of carbon and that they could not be differentiated from other common microorganisms without the ability of utilizing hydrocarbon as a sole source of carbon. ${ }^{1)}$ Besides, they were isolated not only from soils and waters in contact with hydrocarbon in oil-fields and petroleum refineries, but also from common materials such as field soils, garden soils, sea waters and river waters. ${ }^{2 \prime}$

It must be very important for the fermentation industry to employ hydrocarbons as a carbon source material instead of saccharides, which are more costly than hydrocarbons and have been employed as a carbon source

1) G. W. Fuhs, Arch. Microbiol., 39, 374 (1961).

2) R. Yamada, J. Takahashi and K. Kobayashi, This Journal, 27, 390 (1963). material for many years. The production of microbial cell substances from hydrocarbons has been studied by some investigators in order to produce protein and other valuables on commercial base. In 1963, Champagnat et al. reported that the petroleum fractions had been used as substrates for the cultivation of hydrocarbon-utilizing yeasts, from which proteinvitamin concentrates had been produced." It would be considered more favorable to employ yeasts in order to produce microbial cell substances. The yeasts which have been found to utilize hydrocarbons as a sole source of carbon are as follows: Candida albicans (Komagata et

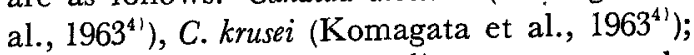
C. lipolytica (Just et al., $1951^{1 \text { ' }}$; Komagata et al.,

3) A. Champagnat, C. Vernet, B. Laine and J. Filosa, Nature, 197, 13 (1963).

4) K. Komagata, T. Nakase and N. Katsuya, presented at the annual Meeting of the Aricultural Chemical Society of Japan in 1953. Abstracts, p. 65 . 
$1963^{4)}$ ); C. rugosa (Iizuka et al., $1963^{51}$; Komagata et al., $1963^{4}$ ); C. tropicalis (Just et al., $1951^{1}$; Komagata et al., 1963 ${ }^{4}$; Kawabata et al., 1965 ${ }^{6}$ ); Debaryomyces sp. (Tausson, 1936'1'); Endomyces sp. (Tausson, $\left.1936^{11}\right)$, Hansenula anomala (Komagata et al., 1963 ${ }^{4}$ ); Hansenula sp. (Rahn, 1906 ${ }^{1 '}$ ); Monilia sp. (Tausson, 1936 ${ }^{13}$ ); Mycotorula japonica (Aida and Yamaguchi, $\left.1964^{71}\right)$; Torula rossa (Rahn, $1906^{11}$ ).

In this report, the isolation and determination of the yeasts, which were isolated from soils and waters in contact with petroleum in Chiba Refinery, Maruzen Oil Co., Ltd., and which could utilize kerosene as a sole source of carbon, were studied in order to produce proteins, fats and nucleic acids, and, in addition, the distribution of the ability of hydrocarbon-utilization in the yeasts was examined with the standard strains.

\section{MATERIALS AND METHODS}

Isolation. Isolation of hydrocarbon-utilizing yeasts was carried out by means of the enrichment culture in the mineral solution containing kerosene as a sole source of carbon $\left(\mathrm{K}_{2} \mathrm{HPO}_{4}, 0.8 \mathrm{~g} ; \mathrm{KH}_{2} \mathrm{PO}_{4}, 0.2 \mathrm{~g}\right.$; $\mathrm{MgSO}_{4} \cdot 7 \mathrm{H}_{2} \mathrm{O}, 0.2 \mathrm{~g} ; \mathrm{NaCl}, 0.2 \mathrm{~g} ; \mathrm{CaCl}_{2} \cdot 2 \mathrm{H}_{2} \mathrm{O}$, $0.05 \mathrm{~g} ; \mathrm{FeSO}_{4} \cdot 7 \mathrm{H}_{2} \mathrm{O}, 0.025 \mathrm{~g} ; \mathrm{Na}_{2} \mathrm{MoO}_{4}, 0.0005 \mathrm{~g}$; $\mathrm{MnSO}_{4} \cdot 4 \mathrm{H}_{2} \mathrm{O}, 0.0005 \mathrm{~g} ; \mathrm{Na}_{2} \mathrm{WO}_{4}, 0.0005 \mathrm{~g} ;\left(\mathrm{NH}_{4}\right)_{2} \mathrm{SO}_{4}$, $2 \mathrm{~g}$; yeast extract, $0.1 \mathrm{~g}$; kerosene, $10 \mathrm{~g}$; agar powder, if added, $20 \mathrm{~g}$; distilled water, 1 liter; $\mathrm{pH} 7.2$ or $4.5)$ by shaking at $25^{\circ} \mathrm{C}$, the subsequent enrichment culture and the plating culture as shown in Table II.

Sample materials. Thirty-seven sample materials served for isolation were collected in Chiba Refinery, Maruzen Oil, Co., Ltd. and included oil-soaked soils, waste waters and so on, as shown in Table I.

Microorganisms for determinination. Eightythree isolates were grouped into the cultural groups with their colony appearances on the mineral agar slants containing kerosene, and the representatives of cultural groups were served for identification.

Determination. Determination was carried out

5) H. Iizuka, S. Shiio and N. Seto, presented at the Annual Meeting of the Agricultural Chemical Society of Japan in 1963. Abstracts, p. 64 .

6) Y. Kawabata, J. Takahashi and K. Yamada, presented at the Annual Meeting of the Agricultural Chemical Society of Japan in 1963. Abstracts, p. 197.

7) T. Aida and K. Yamaguchi, presented at the Annual Meeting of the Agricultural Chemical Society of Japan in 1963. A.bstracts, p. 197. according to Lodder and Kreger-van Rij's methods8) and their modification. A standard inoculum for all

Table I. Sample materials From Chiba ReFINERY, MARUZEN OIL Co., LTD.

Sources

Numbers Materials

about the topping unit

in the waste-treating plant

about the storage tank of crude oil

in the petrochemical plant

in a ditch into the wastetreating plant

in an oil-separator (in operation)

in an oil-separator (off operation)

in the storage tank of crude oil

in the storage tank of cracking oil

in the petrochemical plant in a drain ditch crude oil

\begin{tabular}{lc}
\multicolumn{1}{|c}{ Properties } & $\begin{array}{c}\text { Number } \\
\text { of } \\
\text { Materia }\end{array}$ \\
sand and soil & 4 \\
mud in a ditch & 2 \\
sediment & 1 \\
soil & 4 \\
sand & 1 \\
catalyzing sand & 2 \\
drain water & 4 \\
waste water & 4 \\
waste water & 4 \\
bottom water & 3 \\
bottom water & 1 \\
cooling water & 1 \\
crude oil & 2 \\
& 4 \\
&
\end{tabular}

TABLE II. ISOLATION OF YEASTS FROM SAMPLE MATERIALS $\begin{array}{ccc}\text { 1st } & \text { 2nd } & \text { final isolation } \\ \text { enrichment } & \text { enrichment } & \text { by plating }\end{array}$ culture culture method medium $200 \mathrm{ml}$ of $\quad 20 \mathrm{ml}$ of $20 \mathrm{ml}$ of solution solution agar medium

substrate $2 \mathrm{~g} \quad 0.2 \mathrm{~g} \quad 0.2 \mathrm{~g}$, flood-

ing over aga

pH $\quad 4.5$ and $7.2 \quad 4.5$ and $7.2^{4.5}$ to 5.0

test tube,

vessel 500-ml flask $25 \mathrm{~mm}$ in Petri dish

$\begin{array}{ll}\text { cultiva- } \quad \text { rotary shaker } & \begin{array}{l}\text { diameter } \\ \text { reciprocal } \\ \text { shaker }\end{array}\end{array}$

inoculum $\begin{gathered}\text { solid materials, } \\ 1 \text { to } 2 \mathrm{~g}, \text { or } \\ \text { liquid }\end{gathered}$ enrichment $\begin{aligned} & 1 \text { loop of } 2 \mathrm{nd} \\ & \text { enrichment } \\ & \text { culture }\end{aligned}$



tem- $\quad 25^{\circ} \mathrm{C} \quad 25^{\circ} \mathrm{C} \quad 25^{\circ} \mathrm{C}$

period 7 days 7 days $\quad \begin{aligned} & \text { more than } \\ & 7 \text { days }\end{aligned}$

8) J. Lodder and N. J.W. Kreger-van Rij, "The Yeasts, A Taxonomic Study" (1952). 
tests was one drop of suspension including one loopful of I-week culture on the mineral agar containing kerosene in $3 \mathrm{ml}$ of sterile water or one loopful of the 1 -week culture, and all test media except gelatin stabs were incubated at $25^{\circ} \mathrm{C}$.

Morphological characteristics. Shape and size of the cells were measured with 20 cells of 3-day cultures in the malt extract broth and on the malt extract agar and of 1- to 2-week cultures in the mineral solution containing kerosene. Malt extract broth is composed of: malt extract (Difco), $25 \mathrm{~g}$; distilled water, 1 liter; $\mathrm{pH}$ not adjusted.

Vegetative reproduction was observed by a phase contrast microscope on a slide culture of Lodder and Kreger-van Rij for a month. Ascospore formation was examined with the cells incubated on Gorodkowa agar, on gypsum blocks in water, and in mineral solution without kerosene and ammonium sulphate which was shaken, on 3 days, 7 days, 14 days, 21 days and 30 days, by means of phase contrast microscope and also examined with the cells stained by Schaeffer-Fulton's modification of Wirzt's method.9)

Cultural characteristics. Appearances of cultures were observed in malt extract broth, on malt extract agar slant, on potato glucose agar slant and on mineral agar slant containing kerosene after 3 days' and 7 days' cultivation.

Physiological characteristics. Fermentation was observed on gas and acid production everyday for 10 days in Wickerham's test broth containing each one of sugars tested, with a Durham tube for fermentation. The medium without sugar was served for comparison. ${ }^{10)}$ The sugars tested were D-glucose, Dgalactose, saccharose, maltose, lactose, raffinose, Dxylose, L-arabinose and D-mannitol. Assimilation of carbohydrates was observed on turbidity in Wickerham's test broth for assimilation after 1, 2, 3, and 4 weeks. The medium without sugar was served for comparison. ${ }^{10)}$ The carbohydrates tested were Dglucose, D-galactose, saccharose, maltose, lactose, D-xylose, L-arabinose, ethanol, D-mannitol, sodium citrate and sodium acetate. Production of acid was observed on Lodder and Kreger-van Rij's test agar slant (yeast extract, $1.5 \mathrm{~g}$; Polypepton, $2.5 \mathrm{~g}$, D-glucose, $50 \mathrm{~g}$, calcium carbonate, $5 \mathrm{~g}$; agar $20 \mathrm{~g}$; distilled water, 1 liter) after 10 days' cultivation. In the case of assimilation of nitrate, growth in Wickerham's test

9) Society of American Bacteriologists, Manual of Methods for Pure Culture Study of Bacteria (1954).

10) L. J. Wickerham, "Taxonomy of Yeasts, U.S. Dept. of Agri., Tech. Bull.", No. 1029 (1951). broth with potassium nitrate was compared with that in the broth containing ammonium sulfate as source of nitrogen, which was observed at intervals for 4 weeks.10) For the presence of amylase, cultures were tested with a drop of iodine solution for the presence of starch breakdown products, after 1 and 2 weeks' incubation in Wickerham's test broth for assimilation, containing $2 \mathrm{~g}$ of soluble starch in 1 liter of the mineral solution. For the presence of protease, microorganisms were examined for gelatin liquefaction in gelatin stab, the appearance and the extent of which were noted at regular intervals for a month at $20^{\circ} \mathrm{C}$. Lipase formation was detected on the triolein agar plate and tributyrin agar plate by means of Anderson's simple triglyceride technique ${ }^{11}$ ) and on beef suet agar plate of Lodder and Kreger-van Rij on 3 days, 7 days or 14 days. Production of starchlike compounds was determined by appearance of violet color on 10 days or 14 days streak culture by flooding Lugol's solution over. ${ }^{8)}$ Splitting of arbutin was determined by appearance of brown color around streak cultures within 10 days.8) Reaction in litmus milk was determined by changes in appearance for a month. ${ }^{8}$ Kerosene utilization of standard strains was detected with growth in mineral solution containing kerosene as a sole source of carbon, read after incubation for 14 days; strains which showed growth after two serial subcultures were recorded as positive.

\section{TABLE III. SAMPE MATERIALS WHICH YEASTS WERE ISOLATED FROM}

\begin{tabular}{|c|c|c|c|}
\hline Sources & Properties & $\begin{array}{c}\text { Numbers } \\
\text { of }\end{array}$ & $\begin{array}{c}\text { Strains } \\
\text { isolated at }\end{array}$ \\
\hline & & Materials & $\mathrm{p} \overbrace{\mathrm{H}}^{\mathrm{pH}}$ \\
\hline
\end{tabular}

$\begin{array}{llllr}\begin{array}{c}\text { in the waste-treating } \\ \text { plant }\end{array} & \text { soil } & 1 & & 1 \\ \begin{array}{c}\text { about the storage tank } \\ \text { of crude oil }\end{array} & \text { sand } & 1 & 5 & \\ \begin{array}{c}\text { about the topping } \\ \text { unit }\end{array} & \begin{array}{c}\text { sand and } \\ \text { soil }\end{array} & 1 & & 2 \\ \begin{array}{c}\text { in a ditch into the } \\ \text { waste-treating plant }\end{array} & \begin{array}{l}\text { drain } \\ \text { water }\end{array} & 3 & & 23 \\ \begin{array}{c}\text { in an oil separator } \\ \text { waste }\end{array} & \begin{array}{l}\text { water } \\ \text { waperation) }\end{array} & 2 & 15 & 15 \\ \begin{array}{l}\text { in an oil separator } \\ \text { waste }\end{array} & \begin{array}{l}\text { water } \\ \text { wateration) }\end{array} & 2 & & 17 \\ \text { in a drain ditch } & \text { crude oil } & 1 & & 5 \\ & & 11 & 20 & 63\end{array}$

11) G.A. de Vries, Contribution to the knowledge of the genus Cladosporium Link ex Fr. Baarn, Holland (1952). 


\section{RESULTS}

\section{Isolation}

As shown in Table III, 83 strains of yeasts were isolated from 10 out of 37 sample materials, most of which were waste water samples. In most cases, more strains of yeasts were isolated in $\mathrm{pH} 4.5$ than in $\mathrm{pH} 7.2$ of the medium for isolation, but, from waste water in an oil separator in operation, a large number of yeasts were isolated in pH 7.2 of the medium as well as in $\mathrm{pH}$ 4.5. This fact shows that operation of the oil separator would produce a good effect upon multiplication of yeast cells.

\section{Determination}

All of isolates were asporogenous yeasts, utilizing kerosene well as a sole source of carbon and showing good growth on malt extract agar, potato-glucose agar etc. Their descriptions are as follows;

Candida tropicalis (Castellani) Berkhout

Strains: Pk-51, 190, 191, 192, 233, 234, 235 ; 237 and 239 .*

These strains were considered to belong to the genus Candida, forming no ascospore, having oval cells and developing pseudomycelium, though they could produce a considerable amount of acid transiently during the cultivation. The properties of isolates were a little different from those of the original in respect of such properties as growth in malt extract, ethanol assimilation and reaction in litmus milk. Furthermore, Pk-237 and $\mathrm{Pk}-239$ were differentiated from the others with the streak culture on malt agar and splitting of arbutin. In spite of these facts, they should come within the category of $C$. tropicalis, for these isolates were identical with this species in many other properties important for it.

Growth in malt extract: Cells are short-oval to oval, sometimes round, $(3 \sim 10) \times(4 \sim 10) \mu$. Besides pseudomycelium, some true mycelia

\footnotetext{
* asterisked strains have asterisked properties.
}

are produced. A sediment and a membrane are formed.**

Streak culture on malt agar: Cream-colored to yellowish, tough, surface hirsute or smooth, ${ }^{*}$ smooth margin surrounded by mycelium.

Slide cultures: Pseudomycelium develops abundantly, true mycelium formed, verticils developed, blastoconidia develop along pseudomycelial cells.

Ferment D-glucose, D-galactose, saccharose and maltose. Assimilate D-glucose, D-galactose, saccharose, maltose, D-xylose, L-arabinose, ethanol, ${ }^{* *}$ D-mannitol, acetate and citrate.

Production of acid: Positive.

Assimilation of potassium nitrate: Negative.

Enzymes: Amylase negative; Protease negative; Lipase positive with beef suet and tributyrin, and negative with triolein.

Production of starch-like compounds: Negative.

Splitting of arbutin: Positive or negative.* Reaction in litmus milk: No change. ${ }^{* *}$

Source: Soil and water in Chiba Refinery, Maruzen Oil Co., Ltd., 1964.

Candida guilliermondii (Castellani) Langeron et Guerra

Strains: $\mathrm{Pk}-236$ and 241.

These strains were similar to $C$. guilliermondii except ethanol assimilation and were identified with this species.

Growth in malt extract: Cells are shortoval, small, $(2 \sim 4) \times(2.5 \sim 5) \mu$. A sediment is formed.

Streak culture on malt agar: Cream-colored, soft, smooth and glistening.

Slide cultures: Pseudomycelium consists of chains of stalagmoid cells.

Ferment D-glucose and saccharose. Raffnose weakly fermented. Assimilate D-glucose, D-galactose, saccharose, D-xylose, L-arabinose, acetate and citrate.

Production of acid: Positive.

Assimilation of potassium nitrate: Negative. Enzymes: Amylase negative; Protease nega-

** double-asterisked properties are different from those of the original. 
tive; Lipase positive with beef suet and tributyrin, and negative with triolein.

Production of starch-like compounds: Negative.

Splitting of arbutin: Positive.

Reaction in litmus milk: No change.

Source: Drain water in a ditch into the waste-treating plant in Chiba Refinery, Maruzen Oil Co., Ltd. 1964.

Candida intermedia (Ciferri et Ashford) Langeron et Guerra

Strains: $\mathrm{Pk}-238$ and 243 . $^{*}$

These strains were similar to $C$. intermedia except ethanol assimilation and there are considerable variations between these strains in respect of streak cultures on malt extract, growth in malt broth and maltose fermentation.

Growth in malt extract: Cells are oval, usually in short chains, $(2 \sim 5.5) \times(2.5 \sim 7.5) \mu$. A sediment or a sediment a ring and a pellicle* are formed.

Streak culture on malt agar: White-yellowish or whitish, soft, glistening and smooth or wrinkled.

Slide cultures: Pseudomycelium is not very well developed, and there is not much differences between cells of pseudomycelium and blastospores.

Ferment D-glucose, D-galactose, saccharose and raffinose for one third. Maltose fermented or not.* Assimilate D-glucose, D-galactose, saccharose, maltose, lactose, $\mathrm{D}$-xylose, L-arabinose, ethanol, ${ }^{* *}$ D-mannitol, acetate and citrate.

Production of acid: Positive.

Assimilation of nitrate: Negative.

Enzymes: Amylase negative; Protease negative; Lipase positive with tributyrin and negative with beef suet and triolein.

Production of starch-like compounds: Negative.

Splitting of arbutin: Positive.

Reaction in litmus milk: No change.

Source: Soil, water and crude oil in a drain ditch in Chiba Refinery, Maruzen Oil Co., Ltd., 1964.
Candida pulcherrima (Lindner) Windisch

Strain: Pk-229.

This strain was similar to C. parapsilosis in the points of formation of blastoconidia in a slide culture and cream-colored streak culture on the malt extract, but, agreeing physiologically with C. pulcherrima, this microorganism was identified with C. pulcherrima.

Growth in malt extract: Cells are round to short-oval, $(2 \sim 4.5) \times(2 \sim 6) \mu$. A sediment is formed.

Streak culture on malt agar: Cream-colored, soft, glistening and smooth.

Slide cultures: Pseudomycelium is well developed, blastospores sometimes form small chains, and blastoconidia are formed. ${ }^{* *}$

Ferment D-glucose only. Assimilate D-glucose, D-galactose, saccharose, maltose, $\mathrm{D}$-xylose, L-arabinose, ethanol, D-mannitol, acetate and citrate. Production of acid: Positive.

Assimilation of nitrate: Negative.

Enzymes: Amylase negative; Protease negative; Lipase positive with tributyrin, weakly positive with beef suet and negative with triolein.

Production of starch-like compounds: Negative.

Splitting of arbutin: Positive.

Source: Soil in the waste-treating plant in Chiba Refinery, Maruzen Oil Co., Ltd., 1964. Torulopsis pinus Lodder et Kreger-van Rij

Strain: Pk-150.

This microorganism is not physiologically active and not similar to any species listed in Lodder and Kreger-van Rij's descriptions. However, it would be considered as a variety of Torulopsis pinus according to Lodder and Kreger-van Rij's key to the species, for it agrees with $T$. pinus in respect of sugar utilization, though differing from the latter in some important properties, such as nitrate assimilation, capsule formation and cultural characteristics.

Growth in malt extract: Cells are around, slightly oval, $(2.5 \sim 6) \times(3 \sim 6) \mu$, not surrounded by a capsule.** A pellicle is formed. ${ }^{* *}$ 
Streak culture on malt agar: Smooth, was poured, and only Candida tropicalis was grayish olive to olive.**

isolated from the waste waters of the oil

Slide cultures: No pseudomycelium is formed. separator, as shown in Table IV.

No fermentation. Assimilate D-glucose and acetate. Production of acid: Negative.

Assimilation of nitrate: Positive.**

Enzymes: Amylase negative; Protease negative; Lipase positive with tributyrin, negative; with beef suet and triolein.

Production of starch-like compounds: Negative.

Splitting of arbutin: Negative.

Reaction in litmus milk: No change.

Source: Sand about the storage tank of crude oil in Chiba Refinery, Maruzen Oil Co., Ltd., 1964.

\section{Relation of the isolates with origin}

From drain waters in a ditch flowing in the waste-treating plant, Candida intermedia, $C$. guilliermondii and C. tropicalis were isolated, where the former two species were swarmed in large numbers. However, the latter would turn out to surpass the formers in numbers in the oil separator, into which the drain

TABLE IV. Isolates AND THeIR ORIGINS

\section{Origins}

soil in the wastetreating plant

sand about the storage tank of $T$. pinus-5 crude oil

sand and oil about topping unit

drain water in a ditch into the waste-treating plant Isolates-its numbers

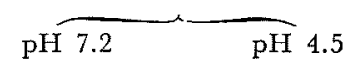

C. pulcherrima-1

C. intermedia-9
C. intermedia*-2
C. tropicalis*-3

waste-water in an oil separator (in operation)

C. tropicalis-15 C. tropicalis-14

waste-water in an oil separator (off operation)

C. tropicalis*-1

C. tropicalis- 17

crude oil in a drain ditch
TABLE V. ABILITY OF STANDARD YeAsts Strains TO UTILIZE KeROSENE AS A Sole SOURCE OF CARBON

To Utilize

kerosene

Strains employed

able Candida albicans IAM 4888

C. arborea IAM 4147

C. lipolytica IAM 4947

C. tropicalis IAM 4862 and IAM 4924

not Brettanomyces bruxellensis IFO 677

Candida albicans IAM 4905

C. guilliermondii IAM 4412

C. krusei IAM 4801

C. mycoderma IAM 4564

C. parapsilosis IAM 4488

C. pseudotropicalis IAM 4829

C. pseudotropicalis var. lactosa IAM 4843

C. utilis IAM 4215, IAM 4220 and IAM

4233

Cryptococcus neoformans IAM 4514 and IAM 4772

Debaryomyces hansenii IAM 4356

Enodmyces magnusii IAM 4754

Endomycopsis capsularis IAM 4307

Eremascus fertilis IFO 691

Hanseniaspora valbyensis IAM 4010

Hansenula anomala IAM 4213 and IAM 4239

Kloeckera apiculata IAM 4018 and IAM 4438

Lipomyces starkeyi IAM 4753

Nadsonia fulvescens IFO 666

Nematospora coryli IFO 658

Pichia membranaefaciens IAM 4025 and IAM

4154

Pityrosporum ovale IFO 656

Rhodotorula glutinis IAM 4757

Saccharomyces cerevisiae IAM 4428, IAM 4702 and IAM PG 1-1

S. chevalieri IAM OG 1-39

S. elegans IAM PG 5-95

Saccharomycodes ludwigii IAM 4380

Schizosaccharomyces pombe IFO 340

Schwanniomyces occidentalis IAM 4332

Sporobolomyces salmonicolor IAM 4764

Torulopsis colliculosa IAM 4426

Trichosporon cutaneum IAM 4450

Trigonopsis variabilis IAM 4443 
Distribution of the ability of utilizing kerosene as a sole source of carbon in the type culture collection of the yeasts

It happened that most of yeast isolates utilizing kerosene as a sole source of carbon would belong to the genus Candida. Therefore, 46 yeast strains of $\mathrm{IAM}^{* 11}$ and IFO ${ }^{* 21}$ type culture collections were tested for utilizing kerosene as a sole source of carbon in order to clarify the distribution of the ability of utilizing kerosene in the standard strains of the yests as shown in Table $\mathrm{V}$. Considering the result, it seemed that most of yeasts utiliz-

Table VI. Cell Yields, Microorganisms being Cultured with Kerosene as a Sole SOURCE OF CARBON

Microorganisms

$\begin{array}{llr}\text { Candida tropicalis } & \mathrm{Pk}-51 & 43.8 \\ & \mathrm{Pk}-190 & 39.4 \\ & \mathrm{Pk}-191 & 54.7 \\ & \mathrm{Pk}-192 & 52.2 \\ & \mathrm{Pk}-233 & 314.0 \\ & \mathrm{Pk}-234 & 45.6 \\ & \mathrm{Pk}-235 & 7.7 \\ & \mathrm{Pk}-237 & 173.0 \\ & \mathrm{Pk}-239 & 66.1 \\ & \mathrm{Pk}-236 & 37.2 \\ \text { Candida guilliermondii } & 73.2 \\ \text { Candida intermedia } & \mathrm{Pk}-238 & 43.0 \\ & \mathrm{Pk}-243 & 46.3 \\ \text { Candida pulcherrima } & \mathrm{Pk}-229 & 7.4 \\ \text { Torulopsis pinus } & \mathrm{Pk}-150 & 52.0 \\ \text { Candida albicans } & \text { IAM } 4888 & \end{array}$

* mg of lyophilized cells, gained from $150 \mathrm{ml}$ of cultures in $500-\mathrm{ml}$ flasks for 2 weeks at $25^{\circ} \mathrm{C}$. ing kerosene as a sole source of carbon would belong to the genus Candida and that the ability of utilizing kerosene would not be such a property as could distinguish a species.

Possibility of producing microbial cell substances

Production of microbial cells, which were gathered by means of centrifugation from 2 weeks cultures of the isolates, in mineral solution containing kerosene is shown in Table VI. There are variations among cell yields of the isolates, which seemed to result from variations in distribution of kerosene and supply of oxygen in cultures. In production of microbial cells with $C$. tropicalis $\mathrm{Pk}-233$, employing glucose as a sole source of carbon, $0.11 \mathrm{~g}$ of cells (dried weights) were gained from $1 \mathrm{~g}$ of glucose, while, in the case of kerosene, $0.074 \mathrm{~g}$ to $0.092 \mathrm{~g}$ of cells (dried weights) were gained from $1 \mathrm{~g}$ of kerosene, though there were a good deal of remnants not utilized, as shown in Table VII. Therefore, it seemed that employing kerosene for producing microbial cell substances was not always inferior to employing glucose. In addition, C. tropicalis $\mathrm{Pk}$-strains, C. guilliermondii $\mathrm{Pk}-236$ and $C$. pulcherrima $\mathrm{Pk}-229$ could produce considerable amounts of riboflavin from kerosene as well as from glucose, which was diffusible into the medium.

Acknowledgements. The authors were indebted to Prof. Dr. H. Iizuka and Mr. H. Akamatsu of the Inststute of Applied Micro-

Table ViI. Production of the Cells of Candida tropicalis Pk-233 with Glucose or Kerosene as a Sole source of Carbon

\begin{tabular}{lcccc} 
& \multicolumn{2}{c}{ Carbon sources kerosene } \\
\cline { 2 - 5 } & Glucose & 1 & 2 & 3 \\
starting amounts of substrates* & & 10.39 & 10.32 & 10.39 \\
amounts of substrates consumed for 2 weeks* & 9.274 & 1.86 & 2.28 & 1.90 \\
consurned/employed $\times 100$ & 97.7 & 18.1 & 22.1 & 18.3 \\
cell yields, lyophilized* & 0.9558 & 0.1838 & 0.1888 & 0.1748 \\
cell yields/consumed substrates & 0.11 & 0.074 & 0.083 & 0.092
\end{tabular}

* $\mathrm{g}$ in $200 \mathrm{ml}$.

*1) Institute of Applied Microbiology, the University of Tokyo.

*2) Institute for Fermentation, Osaka. 
biology, the University of Tokyo, and to Dr. members of the Division of Application T. Hasegawa of the Institute for Fermenta- Technology, Fermentation Research Institute, tion, Osaka, for kindly supplying their for their interest and encouragement during standard strains of yeasts and to Prof. $H$. the course of this work.

Murooka, Nihon University, and to the 